UDK $577.1: 61$

ISSN 1452-8258

J Med Biochem 39: 328-335, 2020

\title{
MR-proADM AND MR-proANP LEVELS IN PATIENTS WITH ACUTE PULMONARY EMBOLISM
}

\author{
NIVOI MR-proADM I MR-proANP KOD PACIJENATA \\ SA AKUTNOM PLUCNOM EMBOLIJOM
}

\author{
Önsel Öner ${ }^{1}$, Figen Deveci ${ }^{1}$, Selda Telo ${ }^{2}$, Mutlu Kuluöztürk ${ }^{1}$, Mehmet Balin ${ }^{3}$ \\ ${ }^{1}$ Department of Pulmonary Medicine, Firat University, School of Medicine, Elazig, Turkey \\ ${ }^{2}$ Department of Biochemistry, Firat University, School of Medicine, Elazig, Turkey \\ ${ }^{3}$ Department of Cardiology, Firat University, School of Medicine, Elazig, Turkey
}

\section{Summary}

Background: The aim of this study was to determine levels of Mid-regional Pro-adrenomedullin (MR-proADM) and Mid-regional Pro-atrial Natriuretic Peptide (MR-proANP) in patients with acute pulmonary embolism (PE), the relationship between these parameters and the risk classification in addition to determining the relationship between 1- and 3month mortality.

Methods: $82 \mathrm{PE}$ patients and 50 healthy control subjects were included in the study. Blood samples for MR-proANP and MR-proADM were obtained from the subjects prior to the treatment. Risk stratification was determined according to sPESI (Simplified Pulmonary Embolism Severity Index). Following these initial measurements, cases with PE were assessed in terms of all causative and PE related mortalities.

Results: The mean serum MR-proANP and MR-proADM levels in acute PE patients were found to be statistically higher compared to the control group ( $p<0.001$, $p<$ 0.01 ; respectively) and statistically significantly higher in high-risk patients than low-risk patients ( $p<0.01$, p $<$ 0.05 ; respectively). No statistical difference was determined in high-risk patients in case of sPESI compared to low-risk patients while hospital mortality rates were higher. It was determined that the hospital mortality rate in cases with MR-proANP $\geq 123.30 \mathrm{pmol} / \mathrm{L}$ and the total 3-month mortality rate in cases with MR-proADM $\geq 152.2 \mathrm{pg} / \mathrm{mL}$ showed a statistically significant increase.

\section{Kratak sadržaj}

Uvod: Cilj ove studije bio je da utvrdi nivo midregionalnog proadrenomedulina (MR-proADM) i midregionalnog proatrijalnog natriuretskog peptida (MR-proANP) kod pacijenata sa akutnom plućnom embolijom (PE), odnos između ovih parametara i klasifikaciju rizika uz utvrđivanje odnosa smrtnosti od 1 do 3 meseca.

Metode: $U$ ispitivanje su uključena 82 pacijenta sa $P E$ i 50 zdravih ispitanika. Uzorci krvi za MR-proANP i MR-proADM su uzeti od subjekata pre tretmana. Stratifikacija rizika određena je prema sPESI (pojednostavljeni indeks ozbiljnosti plućne embolije). Nakon ovih početnih merenja, slučajevi sa PE su ocenjivani u smislu svih uzroka i smrtnosti povezanih sa PE.

Rezultati: Otkriveno je da su prosečni nivo MR-proANP u serumu kod pacijenata sa akutnom PE statistički viši u poređenju sa kontrolnom grupom ( $p<0,001$, $p<0,01$; respektivno) i statistički značajno veći kod visoko rizičnih pacijenata u poređenju sa pacijentima niskog rizika ( $p<$ $0,01, p<0,05$; respektivno). Nije utvrđena statistička razlika kod visoko rizičnih pacijenata u slučaju sPESI u poređenju sa pacijentima niskog rizika, dok je stopa bolničke smrtnosti bila veća. Utvrđeno je da stopa smrtnosti u bolnici u slučajevima sa MR-proANP $\geq 123,30 \mathrm{pmol} / \mathrm{L}$ i ukupna tromesečna stopa smrtnosti u slučajevima sa MR-proADM $\geq 152,2 \mathrm{pg} / \mathrm{mL}$ pokazuje statistički značajno povećanje. Zaključak: Ova studija je pokazala da MR-proANP i MRproADM mogu biti važan biohemijski pokazatelj za

Address for correspondence:

Dr Figen Deveci

Firat University Faculty of Medicine

Department of Chest Diseases

23119 Elazig, Turkey

phone: +90 424 2333555/2858,

e-mail: fgndeveci@yahoo.com 
Conclusions: This study showed that MR-proANP and MRproADM may be an important biochemical marker for determining high-risk cases and predicting the mortality in PE patients and we believe that these results should be supported by further and extensive studies.

Keywords: pulmonary embolism, MR-proADM, MRproANP, mortality

\section{Introduction}

Classification of the Pulmonary embolism (PE) patients for early mortality as a high-risk, intermediate-risk or low-risk determines the treatment options and prognosis (1). Clinical parameters [Pulmonary Embolism Severity Index (PESI), simplified PESI score (sPESI)], right ventricular dysfunction (RVD) markers, thrombotic load markers and myocardial damage markers in hemodynamically stable acute symptomatic PE cases are the most commonly used prognostic factors. In the determination of the risk of early poor prognosis in normotensive PE cases, none of the findings, such as high risk in clinical scoring, presence of RVD or increased levels of cardiac markers, are sufficient by itself. It is believed that prognostic evaluation results will be strengthened if these methods are used together (2).

Adrenomedullin (ADM) is a vasodilating peptide released from endothelial tissue in organs such as lungs, heart and gastrointestinal tract. It has natriuretic and antiproliferative effects. ADM is released in a pro-ADM form that is an inactive precursor. Midregional pro-ADM (MR-proADM), a more stable peptide, was found to be an important prognostic marker (3). A-type natriuretic peptide (ANP) from the natriuretic peptide family increases in inflammatory conditions and hemodynamic stress. MR-proANP, the Midregional fragment of ANP, is more stable in blood than ANP. MR-proANP and MR-proADM were reported to have a significant diagnostic and prognostic value in a series of cases with acute dyspnea (4).

In our study, the aim was to determine the levels of the new cardiac markers, MR-proADM and MRproANP, in acute PE cases. Additionally, it was aimed to determine the relationship between these parameters and the severity of disease in addition to risk classification and mortality from $1^{\text {st }}$ and $3^{\text {rd }}$ months in hospital and total 3-month mortality rate.

\section{Materials and Methods}

\section{Patient population and study design}

Eighty-two patients with acute PE cases who were referred to Chest Disease Polyclinic and Emergency Service in the Medicine Faculty of Firat University and diagnosed with PE by multidetector pulmonary CT angiography were included in the study, and 50 gender- and age-matched healthy sub- određivanje slučajeva visokog rizika i predviđanja smrtnosti kod pacijenata sa PE i verujemo da bi ovi rezultati trebali biti podržani daljim i opsežnim studijama.

Ključne reči: plućna embolija, MR-proADM, MRproANP, smrtnost

jects were included in the study as the control group. Ethical approval was obtained by the institutional review board (27.12.2016-178051). Significant heart valve disease, acute coronary syndrome or left ventricular ejection fraction less than $40 \%$ were excluded from the study. Demographic data and physical examination findings of PE cases were recorded. Blood samples for the MR-proADM and MR-proANP, and arterial blood gases (ABG) samples were obtained prior to the initiation of the treatment in PE patients and healthy controls. Furthermore, plasma D-dimer, troponin I (Thl) and serum brain natriuretic peptide (BNP) values, which were routinely obtained to determine the risk stratification in acute PE patients, were recorded. The severity of acute PE was determined by systemic systolic blood pressure, initial echocardiographic evaluation, RVD findings, plasma Tnl and BNP levels as indicated in the European Society of Cardiology PE Guidelines (5). The patients with a sPESI risk score of 0 were regarded as low-risk patients, and those with a sPESI score $\geq 1$ were regarded as high-risk patients. After these initial measurements, acute PE patients were evaluated within a period of hospitalization for all the reasons and PE-related mortality on the $1^{\text {st }}$ and $3^{\text {rd }}$ months and total mortality rate.

\section{Patients' follow-up}

All patients completed follow-up at $1^{\text {st }}$ and $3^{\text {rd }}$ months after enrollment. Their follow-up included one telephone interview and two face-to-face evaluations for observation during the 3 months of study participation. Then, semi-annual contacts, alternating between face-to-face evaluations (clinic visits or home visits for housebound patients) and telephone calls as well as periodic reviews of patients' hospital charts were conducted. During each visit/contact, the researchers included in the study interviewed patients and/or patients' relatives to obtain information about mortality.

\section{Arterial blood gas examination ( $A B G$ )}

$A B G$ samples collected from the radial artery in room temperature were examined by blood gas analysis device (Rapidlab 348, Biobak; Bayer Diagnostic, UK). 


\section{Echocardiography (ECHO)}

Pulmonary artery pressure (PAP) and RVD were evaluated by Doppler ECHO in patients with acute PE. $\mathrm{ECHO}$ was performed by a single $3.4 \mathrm{MHz}$ transducer probe with two-dimensional, classical and tissue Doppler. sPAPs $>36 \mathrm{mmHg}$ on the echocardiographic examination were regarded as pulmonary hypertension (PH) (6). RVD was defined when at least one of the following conditions were present: right ventricle hypokinesia (asymmetrical or delayed contraction), systolic paradoxical movement in the septal wall, right ventricular dilation (end-diastolic diameter $>30 \mathrm{~mm}$, or right/left ventricle diameter ratio > 1) (7).

\section{Biochemical Analyses}

Routine biochemical measurements were performed in our central laboratory (ADVIA 2400, Siemens Healthcare Diagnostics Inc., Tarrytown, USA). Serum BNP and Tnl concentrations were performed on the ADVIA Centaur XP immunoassay analyzer (Siemens Healthcare Diagnostics Inc., Tarrytown, NY). Plasma D-dimer levels were assessed by using the BCS XP coagulation analyzer (Siemens Healthcare Diagnostics, Marburg, Germany).

Serum MR-proADM and MR-proANP levels were measured with a commercially available kit using an ELISA, Human MR-proADM ELISA kit (Catalogue No: 201-12-7275 Sunred Biological Technology Co. Ltd, Shanghai) with a low sensitivity limit of $2.839 \mathrm{pg} / \mathrm{mL}$. The samples were measured in duplicates in a single experiment. The intra- and interassay coefficients of variance of this kit are $<10 \%$ and $<12 \%$, respectively. The detection range of MRproADM was 3-900 pg/mL, Human MR-proANP ELISA kit (Catalogue No: 201-12-6282 Sunred Biological Technology Co. Ltd, Shanghai with a low sensitivity limit of $1.863 \mathrm{pg} / \mathrm{mL}$, and the detection range of MR-proANP was $2-400 \mathrm{pmol} / \mathrm{L}$.

\section{Statistical analysis}

In the statistical analysis process, IBM Statistical Product and Service Solutions version 21.0 (IBM SPSS Statistics 21 program, Armonk, NY, USA) software was used. Results were expressed as the mean \pm standard deviation and percentage. A p-value of $<$ 0.05 was deemed statistically significant. $X^{2}$ test was used to determine the gender difference. Statistical analysis was performed using Kruskal-Wallis test for multiple-group comparisons; Mann-Whitney $U$ test was performed to test any observed differences for significance. Spearman's correlation was used to assess the nonparametric data. Receiver operating characteristic (ROC) curves were plotted to demonstrate the sensitivity and specificity of the evaluated MR-proADM and MR-proANP.

\section{Results}

Eighty-two patients with acute PE (40 (48\%) males and 42 (51.2\%) females with a mean age of $64.96 \pm 17.24)$ and 50 healthy controls (23 (46\%) males and 27 (54\%) females with a mean age of $66.16 \pm 14.06)$ were included in the study. There was no significant difference in age $(p>0.05)$ and gender ( $\left.p>0.05, X^{2}=0.096\right)$ between the groups.

According to the sPESI index of patients with acute PE, 27 (20.30\%) were at a low risk (Mean age of $56.19 \pm 17.10$ and the male / female ratio of 15 $(55.6 \%) / 12(44.4 \%))$ and $55(41 \%)$ were at a high risk (Mean age of $69.27 \pm 15.73$ and the male/female ratio of $25(45.5 \%) / 30(54.5 \%))$. There was no significant difference in gender $\left(p>0.05, X^{2}\right.$ $=0.096$ ) between high- and low-risk sPESI groups while the mean age of the high-risk cases was statistically higher than the low-risk cases $(p<0.01)$.

Of 82 patients with acute PE, 7 (8.53\%) died during their stay in the hospital. Additionally, 3 of the patients $(3.65 \%)$ died during the 1-month follow-up while another $3(3.65 \%)$ died during the 3-month follow-up. All deaths were due to PE-related mortality (right heart failure, hemodynamic collapse, major bleeding, etc.). Hematological parameters of patients with acute PE were presented in Table I.

The mean serum MR-proANP and MR-proADM concentrations were statistically higher in patients with acute PE compared to the control group and significantly higher in patients with high clinical risk than those with low clinical risk (Figure 1, Table I).

Significant differences were observed between sPESI $\geq 1$ and $\mathrm{sPESI}<1$ groups regarding the BNP, Tnl, platelet levels and sPAP (Table I). There was no statistically significant difference in the hospital mortality between sPESI high-risk patients and low-risk patients while the hospital mortality rate was high in high-risk patients. Additionally, there was no statistically significant difference in $1^{\text {st }}$-month, $3^{\text {rd }}$-month and 3-month total mortality rates between sPESI high- and low-risk groups (Table II).

When cut-off was taken as $\geq 123.3 \mathrm{pmol} / \mathrm{L}$ for MR-proANP with ROC analysis for predicting the high risk of sPESI in patients with acute $P E, A U C$ was found to be 0.727 (95\% Cl; 0.615-0.89, p < 0.01). The sensitivity was $85 \%$ while the specificity was $62 \%$. Furthermore, for the cut-off of $\geq 152.2 \mathrm{pg} / \mathrm{mL}$ in MR-proADM, AUC was $0.643(95 \% \mathrm{Cl} ; 0$. 518$0.767, \mathrm{p}<0.01)$ and the sensitivity was $74 \%$ with a specificity of $60 \%$ (Figure 2 ).

After classifying the patients into two groups according to the cut off value as $123.3 \mathrm{pmol} / \mathrm{L}$ for MR-proANP, the hospital mortality rate was found to be statistically higher in patients with MR-proANP $\geq$ 123.3 (Table III). Additionally, the total mortality rate 
Table I Hematological parameters of patients with acute pulmonary embolism.

\begin{tabular}{|c|c|c|c|c|}
\hline & $\begin{array}{c}\text { Total } \\
\text { Acute PE } \\
(\mathrm{n}=82)\end{array}$ & $\begin{array}{c}\text { sPESI } \geq 1 \\
\text { High risk } \\
(n=55)\end{array}$ & $\begin{array}{c}\text { sPESI }<1 \\
\text { Low risk } \\
(n=27)\end{array}$ & $\begin{array}{c}\text { Control } \\
(n=50)\end{array}$ \\
\hline D-dimer $(\mu \mathrm{g} / \mathrm{L})$ & $4882.5 \pm 5268.5$ & $5617.6 \pm 5871.7$ & $3385.03 \pm 3375.7$ & - \\
\hline $\mathrm{BNP}(\mathrm{ng} / \mathrm{mL})$ & $4022.1 \pm 6533.7$ & $4854.6 \pm 6297.3^{a}$ & $2326.2 \pm 6795.4$ & - \\
\hline $\mathrm{Tnl}(\mathrm{ng} / \mathrm{mL})$ & $0.14 \pm 0.46$ & $0.19 \pm 0.54^{b}$ & $0.06 \pm 0.20$ & - \\
\hline $\mathrm{WBC}\left(10^{3} / \mu \mathrm{L}\right)$ & $8358.4 \pm 4321.6$ & $8887.4 \pm 2817.2$ & $7281.4 \pm 2817.2$ & - \\
\hline Plt $\left(10^{3} / \mu \mathrm{L}\right)$ & $268.1 \pm 103.1$ & $287.2 \pm 110.7^{b}$ & $229.3 \pm 73.03$ & - \\
\hline $\mathrm{sPAP}(\mathrm{mmHg})$ & $42.2 \pm 19.2$ & $44.9 \pm 20.08^{b}$ & $36.7 \pm 16.3$ & - \\
\hline $\mathrm{PaO}_{2}(\mathrm{mmHg})$ & $67.1 \pm 20.7$ & $62.5 \pm 20.3^{a}$ & $76.5 \pm 18.7$ & - \\
\hline $\mathrm{PaCO}_{2}(\mathrm{mmHg})$ & $31.8 \pm 5.9$ & $31.6 \pm 6.2$ & $32.1 \pm 5.2$ & - \\
\hline $\mathrm{pH}$ & $7.42 \pm 0.06$ & $7.43 \pm 0.07$ & $7.42 \pm 0.04$ & - \\
\hline $\mathrm{SaO}_{2}(\%)$ & $88.6 \pm 10.2$ & $86.5 \pm 11.1^{a}$ & $92.89 \pm 6.1$ & - \\
\hline MR-proANP (pmol/L) & $126.09 \pm 38.1^{c}$ & $136.1 \pm 38.4^{a}$ & $105.6 \pm 28.5$ & $79.6 \pm 26.7$ \\
\hline MR-proADM (pg/mL) & $178.5 \pm 82.2^{d}$ & $189.4 \pm 87.8^{b}$ & $156.3 \pm 65.4$ & $142.1 \pm 66.1$ \\
\hline
\end{tabular}

a $p<0.01$; when compared to low-risk acute PE patients, $b \mathrm{p}<0.05$; when compared to low-risk acute PE patients, $c \mathrm{p}<0.001$ : when compared to control group, ${ }^{\mathrm{d}} \mathrm{p}<0.01$; when compared to control group.

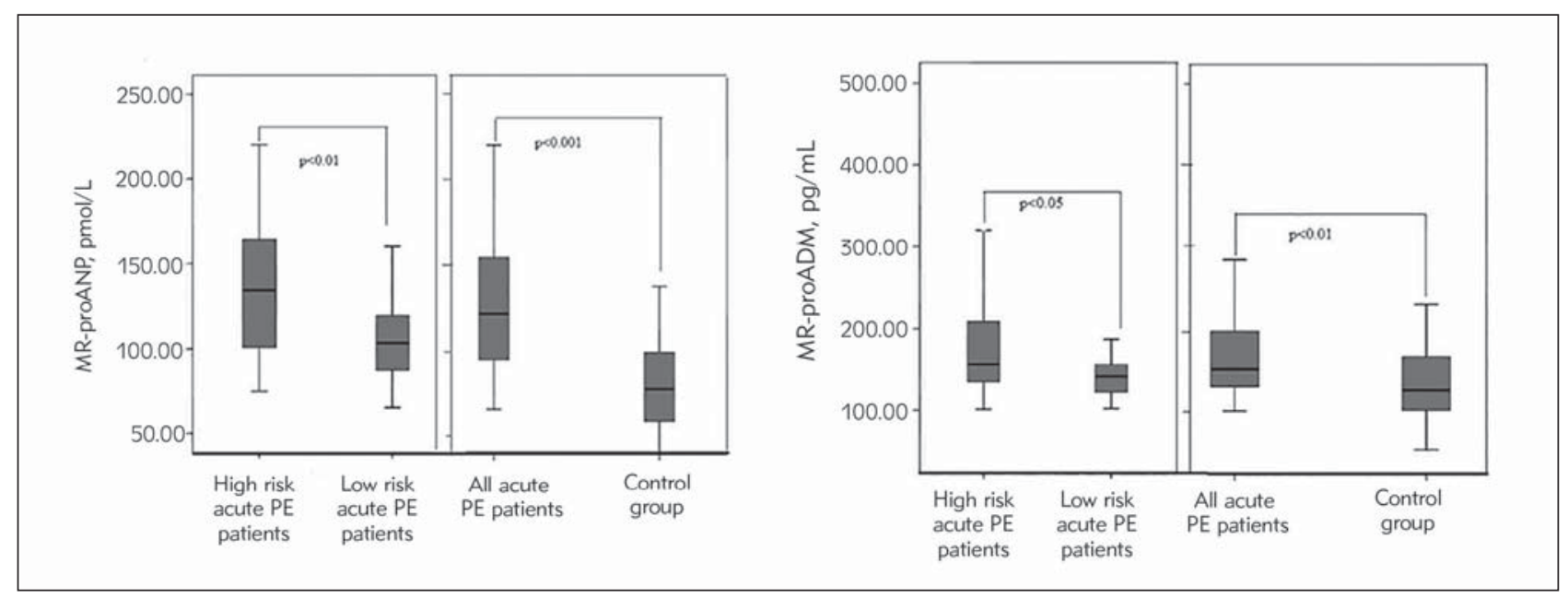

Figure 1 Mean serum MR-proANP and MR-proADM levels of cases.

Table II The hospital, 1 month, 3 months and total 3-month mortality rates in high and low-risk groups according to sPESI.

\begin{tabular}{|c|c|c|c|c|c|c|c|c|}
\hline \multirow{2}{*}{ sPESI } & \multicolumn{2}{|c|}{$\begin{array}{c}\text { Hospitalmortality } \\
\mathrm{n}(\%)\end{array}$} & \multicolumn{2}{|c|}{$\begin{array}{c}1^{\text {th }} \text { month mortality } \\
\mathrm{n}(\%)\end{array}$} & \multicolumn{2}{|c|}{$\begin{array}{c}3^{\text {th }} \text { month mortality } \\
\mathrm{n}(\%)\end{array}$} & \multicolumn{2}{|c|}{$\begin{array}{c}\text { Total mortality } \\
\mathrm{n}(\%)\end{array}$} \\
\cline { 2 - 8 } & Ex & Live & Ex & Live & Ex & Live & Ex \\
\hline $\begin{array}{c}\text { High risk } \\
(\mathrm{n}=55)\end{array}$ & $6(10.9)$ & $49(89.1)$ & $3(6.1)$ & $46(93.9)$ & $2(4.3)$ & $44(95.7)$ & $11(20)$ & $44(80)$ \\
\hline $\begin{array}{c}\text { Low risk } \\
(\mathrm{n}=27)\end{array}$ & $1(3.7)$ & $26(96.3)$ & $0(0)$ & $26(100)$ & $1(3.8)$ & $25(96.2)$ & $2(7.4)$ & $25(92.6)$ \\
\hline$X^{2}, \mathrm{P}$ value & \multicolumn{2}{|c|}{$1.204,>0.05$} & \multicolumn{2}{|c|}{$1.658,>0.05$} & \multicolumn{2}{|c|}{$0.010,>0.05$} & $2.153,>0.05$ \\
\hline
\end{tabular}



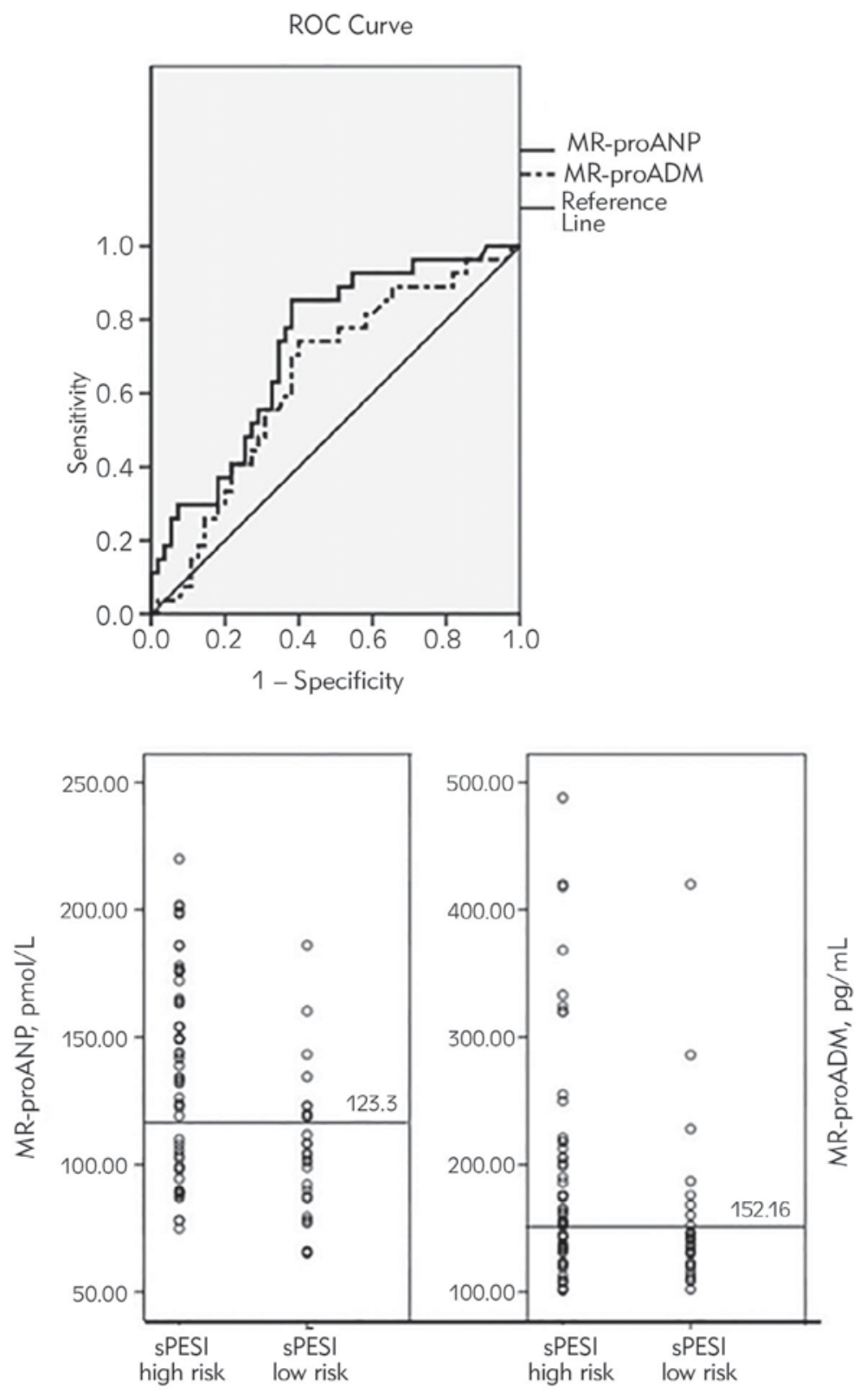

Figure 2 The cut-off levels of MR-proANP and MR-proADM in patients with high-low risk acute PE according to sPESI and receiver operating characteristic (ROC) curve indicating sensitivity and specificity of MR-proANP and MR-proADM to predict of high risk patients.

Table III Hospital mortality rate was found to be statistically higher in patients with MR-proANP $\geq 123.3 \mathrm{pmol} / \mathrm{L}$.

\begin{tabular}{|c|c|c|c|c|c|c|c|c|}
\hline \multirow{2}{*}{ MR-proANP } & \multicolumn{2}{|c|}{$\begin{array}{l}\text { Hospitalmortality } \\
n(\%)\end{array}$} & \multicolumn{2}{|c|}{$\begin{array}{c}1^{\text {th }} \text { month mortality } \\
n(\%)\end{array}$} & \multicolumn{2}{|c|}{$\begin{array}{c}3^{\text {th }} \text { month mortality } \\
n(\%)\end{array}$} & \multicolumn{2}{|c|}{$\begin{array}{c}\text { Total mortality } \\
\mathrm{n}(\%)\end{array}$} \\
\hline & Ex & Live & Ex & Live & Ex & Live & Ex & Live \\
\hline $\begin{array}{l}<123.3 \mathrm{pmol} / \mathrm{L} \\
(\mathrm{n}=42)\end{array}$ & $1(2.4)$ & 41(97.6) & $1(2.4)$ & 40(97.6) & $2(5)$ & 38(95) & $4(9.5)$ & $38(90.5)$ \\
\hline $\begin{array}{l}\geq 123.3 \mathrm{pmol} / \mathrm{L} \\
(\mathrm{n}=40)\end{array}$ & $6(15)$ & $34(85)$ & $2(5.9)$ & $32(94.1)$ & $1(3.1)$ & $31(96.9)$ & $9(22.5)$ & $31(77.5)$ \\
\hline$x^{2}, p$ value & \multicolumn{2}{|c|}{$4.178,<0.05$} & \multicolumn{2}{|c|}{$0.574,>0.05$} & \multicolumn{2}{|c|}{$0.157,>0.05$} & \multicolumn{2}{|c|}{$2.586,>0.05$} \\
\hline
\end{tabular}


Table IV Total 3-month mortality rate was found to be statistically higher in patients with MR-proADM $\geq 152.2 \mathrm{pg} / \mathrm{mL}$.

\begin{tabular}{|c|c|c|c|c|c|c|c|c|}
\hline \multirow{2}{*}{ MR-proADM } & \multicolumn{2}{|c|}{$\begin{array}{l}\text { Hospitalmortality } \\
\text { n (\%) }\end{array}$} & \multicolumn{2}{|c|}{$\begin{array}{c}1^{\text {th }} \text { month mortality } \\
n(\%)\end{array}$} & \multicolumn{2}{|c|}{$\begin{array}{c}3^{\text {th }} \text { month mortality } \\
n(\%)\end{array}$} & \multicolumn{2}{|c|}{$\begin{array}{c}\text { Total mortality } \\
\mathrm{n}(\%)\end{array}$} \\
\hline & Ex & Live & Ex & Live & Ex & Live & Ex & Live \\
\hline $\begin{array}{l}<152.2 \mathrm{pg} / \mathrm{mL} \\
(\mathrm{n}=40)\end{array}$ & $1(2.5)$ & $39(97.5)$ & $1(2.6)$ & $38(97.4)$ & $0(0)$ & $38(100)$ & $2(5)$ & $38(95)$ \\
\hline $\begin{array}{l}\geq 152.2 \mathrm{pg} / \mathrm{mL} \\
(\mathrm{n}=42)\end{array}$ & $6(14.3)$ & $36(85.7)$ & $2(5.6)$ & $34(94.4)$ & $3(8.8)$ & $31(91.2)$ & $11(26.2)$ & $31(73.8)$ \\
\hline$X^{2}, p$ value & \multicolumn{2}{|c|}{$3.645,>0.05$} & \multicolumn{2}{|c|}{$0.436,>0.05$} & \multicolumn{2}{|c|}{$3.499,>0.05$} & \multicolumn{2}{|c|}{$6.896,<0.05$} \\
\hline
\end{tabular}

was found to be statistically higher in patients with MR-proADM $\geq 152.2 \mathrm{pg} / \mathrm{mL}$ (Table $/ \mathrm{V}$ ).

When the correlation between MR-proANP and cardiac markers, and SPAP in patients with acute PE were evaluated; only a positive correlation was determined between MR-proANP and D-dimer levels $(r=$ $0.234, p<0.05$ ). No correlation was determined between MR-proADM and any of the parameters.

When evaluated by logistic regression analysis, only MR-proADM value of $\geq 152.2 \mathrm{pg} / \mathrm{mL}$ was found to be an independent risk factor for 3-month total mortality ( $p<0.05$, OR: 6.742, (\% 95 Cl: 1. 389_ 32.717)).

\section{Discussion}

Our study results showed that serum MRproANP and MR-proADM levels were significantly higher in acute PE patients than in the control group and both of them was especially found to be statistically higher in sPESI $\geq 1$ group. MR-proANP and MRproADM values had a moderate specificity and sensitivity in predicting high sPESI score. Additionally, increased MR-proADM values were an independent risk factor for 3-month total mortality rate in acute PE patients.

The prognostic value and the role of MRproADM in risk stratification were demonstrated in patients with acute heart failure $(8,9)$. Furthermore, recent observational studies showed that proADM is a powerful independent prognostic factor in long-term non-survival in COPD patients (10-13). In the literature, several studies evaluated the role of pro-ADM in patients with community-acquired pneumonia (CAP) (14). According to the study results, MR-proADM was found as a good predictor of short- and long-term allcause mortality in CAP patients. A recently published prospective multicenter study demonstrated that MRproANP and MR-proADM were associated with exercise variables and prognosis in pulmonary arterial hypertension (PAH) and chronic thromboembolic pulmonary hypertension (CTEPH) (15). MR-proADM is a good prognostic indicator of mortality, and it may have a contributory effect in the risk stratification of acute dyspnea patients. Previous studies also reported similar AUC values (0.81) for MR-proADM in predicting 30-day mortality in acute dyspnea patients (16, 17). Another study, which evaluated the diagnostic and prognostic value of MR-proADM and MRproANP in patients with acute dyspnea, found that MR-proANP had a diagnostic value in patients with acute dyspnea while both MR-proANP and MRproADM were independent prognostic factors for 4 years follow-up (18). The study of Heining et al. (19) demonstrated that MR-proADM was the best predictor of non-survival patients with acute heart failure while pneumonia and values $\geq 1.5 \mathrm{nmol} / \mathrm{L}$ were associated with a high risk of death. On the other hand, MR-proANP was found as predictors for the diagnosis of $P E$ in this study, while its predictive potential could not be identified due to the low incidence of this final diagnosis. The predictive value of natriuretic hormones was reported for PE, and its severity and outcome $(20,21)$. Increased levels of the natriuretic peptides, such as ANP, BNP and N-ANP, were found in patients with a high probability of $\mathrm{PE}$ on radionuclide scanning (20). A progressive incremental rise in natriuretic peptide levels with increasing degrees of ventilation-perfusion mismatch within the lung was reported. Therefore, it was believed that there was a direct relationship between perfusion defects and release of natriuretic peptides (20). Few previous studies examined the prognostic value of MRproADM in acute PE patients. These studies reported that MR-proADM was an independent predictor of PE-related mortality $(22,23)$. It was demonstrated that the prognostic accuracy of MRproADM tended to increase over time, C-statistics reaching to 0.84 for PE-related mortality at 24 months while being a nonsignificant predictor for 1 month (23). Moreover, the prognostic superiority of MR-proADM over NTproBNP was also described for acute PE and MRproADM levels were found significantly higher in high-risk acute PE patient compared to hemodynamically stable patients. Therefore, it was thought that plasma levels of MR-proADM reflect the severity of 
acute PE (22). In our study, MR-proADM value of $\geq 152.2 \mathrm{pg} / \mathrm{mL}$ was determined to be an independent risk factor for 3-month total mortality through logistic regression analysis. Similar to the study of Pedowska-Włoszek et al. (22) we found that MRproADM levels were elevated in acute PE patients compared with the control group. Additionally, when we evaluated the role of new cardiac markers, MRproADM and MR-proANP, for risk stratification in patients with acute $P E$, we observed that both markers had an acceptable AUC value. We demonstrated that increased MR-proANP might be related to hospital mortality. For this reason, we believe that MRproADM and MR-proANP may be potential biomarkers in providing additional information on the risk stratification of patients with $\mathrm{PE}$.

MR-proADM is a pluripotent regulatory vasoactive peptide related to a variety of cardiovascular, renal, metabolic, and immunomodulatory effects. It acts as a vasodilator, natriuretic, diuretic, antioxidative, anti-inflammatory, antimicrobial, and metabolic agent $(13,24)$. Up-regulation of MR-proADM was also linked to hypoxia and inflammation (25). Increased ADM levels in final-stage pulmonary disease may be related to the reflection of "high demand" for these compensatory/counter-regulatory effects $(13,26-28)$. The possible physiopathological association between elevated levels of MR-proADM and mortality in PE may be explained by the cardiomyocytes stretch and hypoxia in promoting ADM gene expression $(29,30)$. Weak positive correlations with mean pulmonary arterial pressure and ADM levels were found, and this indicated to the role of severity of vascular impairment at increased ADM levels (28).

\section{References}

1. Konstantinides S, Golldhaber Sz. Pulmonary embolism: Risk assesment and management. Eur Heart J 2012; 33: 3014-22.

2. Aujesky D, Roy PM, Le Manach $C P$, et al. Validation of a model to predict adverse outcomes in patients with pulmonary embolism. Eur Heart J 2006; 27: 476-81.

3. Klip IT, Voors AA, Anker SD, et al. Prognostic value of mid-regional pro-adrenomedullin in patients with heart failure after an acute myocardial infarction. Heart 2001; 97: 892-8.

4. Maisel A, Mueller C, Nowak R, et al. Mid-region pro-hormone markers for diagnosis and prognosis in acute dyspnea: results from the BACH (Biomarkers in acute Heart failure) trial. J Am Coll Cardiol 2010; 55: 2062-76.

5. Konstantinides SV, Meyer G, Becattini C, et al. 2019 ESC Guidelines for the diagnosis and management of acute pulmonary embolism developed in collaboration with the European Respiratory Society (ERS). Eur Heart J 2019. doi: 10.1093/eurheartj/ehz405.

\section{Study limitations}

Our study group consisted of a relatively small group in a single centre. Furthermore, the study group did not include patients with significant heart valve disease, acute coronary syndrome or left ventricular ejection fraction less than $40 \%$. For this reason, our study results should be interpreted carefully. Furthermore, MR-proADM and MR-proANP levels were only measured initially. We could not perform follow-up measurements of the biomarkers. Therefore, we could not make any comments on the marker kinetics and monitoring of treatment response. Our study covered a short follow-up period. Long-term follow-up of these markers may provide more accurate information about their prognostic value in patients with $\mathrm{PE}$.

\section{Conclusions}

The findings of our study indicated that MRproANP and MR-proADM could be a promising new biomarker for determining high-risk cases and predicting the short-term mortality of PE patients. Integration of these markers into sPESI scores may be a contributing element in the determination of the severity of PE in hemodynamically stable patients. Further research is necessary to determine whether MR-proANP and MR-proADM can be used with other validated markers.

\section{Conflict of interest statement}

The authors stated that they have no conflicts of interest regarding the publication of this article.

6. Galiè N, Humbert M, Vachiery JL, et al. 2015 ESC/ERS Guidelines for the diagnosis and treatment of pulmonary hypertension: The Joint Task Force for the Diagnosis and Treatment of Pulmonary Hypertension of the European Society of Cardiology (ESC) and the European Respiratory Society (ERS): Endorsed by: Association for European Paediatric and Congenital Cardiology (AEPC), International Society for Heart and Lung Transplantation (ISHLT). Eur Respir J 2015; 46: 903-75.

7. Golpe R, Pérez-de-Llano LA, Castro-Añón O, et al. Right ventricle dysfunction and pulmonary hypertension in hemodynamically stable pulmonary embolism. Respir Med 2010; 104: 1370-6.

8. Maisel A, Mueller C, Nowak RM, et al. Midregion prohormone adrenomedullin and prognosis in patients presenting with acute dyspnea: results from the $\mathrm{BACH}$ (Biomarkers in Acute Heart Failure) trial. J Am Coll Cardiol 2011; 58: 1057-67. 
9. Maisel A, Mueller C, Nowak R, et al. Mid-region pro-hormone markers for diagnosis and prognosis in acute dyspnea: results from the BACH (Biomarkers in Acute Heart Failure) trial. J Am Coll Cardiol 2010; 55: 2062-76.

10. Stolz D, Christ-Crain M, Morgenthaler NG, et al. Plasma pro-adrenomedullin but not plasma proendothelin predicts survival in exacerbations of COPD. Chest 2008; 134: $263-72$.

11. Zuur-Telgen MC, Brusse-Keizer MG, VanderValk PD, van der Palen J, Kerstjens HA, Hendrix MG. Stable-state midrangepro-adrenomedullin level is a strong predictor of mortality in COPD patients. Chest 2014; 145: 53441.

12. Grolimund E, Kutz A, Marlowe RJ, et al. Long-term prognosis in COPD exacerbation: role of biomarkers, clinical variables and exacerbation type COPD. COPD 2015; 12 : 295-305.

13. Stolz D, Kostikas K, Blasi F, et al. Adrenomedullin refines mortality prediction by the BODE index in COPD: the "BODE-A" index. Eur Respir J 2014; 43: 397-408.

14. Albrich WC, Dusemund F, Ruegger K, et al. Enhancement of CURB65 score with pro-adrenomedullin (CURB65-A) for outcome prediction in lower respiratory tract infections: derivation of a clinical algorithm. BMC Infect Dis 2011; 11: 112

15. Kolditz M, Seyfarth HJ, Wilkens $H$, et al. MR-proADM Predicts Exercise Capacity and Survival Superior to Other Biomarkers in PH. Lung 2015; 193: 901-10.

16. Potocki $M$, Breidthardt $T$, Reichlin $T$, et al. Mid-regional pro-adrenomedullin in addition to b-type natriuretic peptides in the risk stratification of patients with acute dyspnea: an observational study. Crit Care 2009; 13: 122.

17. Cinar O, Cevik E, Acar A, et al. Evaluation of mid-regional pro-atrial natriuretic peptide, procalcitonin, and midregional pro-adrenomedullin for the diagnosis and risk stratification of dyspneic ED patients. Am J Emerg Med 2012; 30: 1915-20.

18. Shah RV, Truong QA, Gaggin HK, Pfannkuche J, Hartmann O, Januzzi JL Jr. Mid-regional pro-atrial natriuretic peptide and pro-adrenomedullin testing for the diagnostic and prognostic evaluation of patients with acute dyspnoea. Eur Heart J 2012; 33: 2197-205.

19. Heining L, Giesa C, Ewig S. MR-proANP, MR-proADM, and PCT in Patients Presenting with Acute Dyspnea in a Medical Emergency Unit. Lung 2016; 194: 185-9.
20. Kiely DG, Kennedy NS, Pirzada O, Batchelor SA, Struthers AD, Lipworth BJ. Elevated levels of natriuretic peptides in patients with pulmonary thromboembolism. Respir Med 2005; 99: 1286-91.

21. Cavallazzi R, Nair A, Vasu T, Marik PE. Natriuretic peptides in acute pulmonary embolism: a systematic review. Intens Care Med 2008; 34: 2147-56.

22. Pedowska-Włoszek J, Kostrubiec M, Kurnicka K, Ciurzynski M, Palczewski P, Pruszczyk P. Mid-regional proadrenomedullin (MR-proADM) in the risk stratification of patients with acute pulmonary embolism. Thromb Res 2013; 132: 506-10.

23. Vuilleumier N, Simona A, Méan M, et al. Comparison of Cardiac and Non-Cardiac Biomarkers for Risk Stratification in Elderly Patients with Non-Massive Pulmonary Embolism. PLoS One 2016; 11: 0155973.

24. Smith JG, Newton-Cheh C, Hedblad B, et al. Distribution and correlates of Mid-regional pro-adrenomedullin in the general population. Clin Chem 2009; 55: 1593-5.

25. Stolz D, Boersma W, Blasi F, et al. Exertional hypoxemia in stable COPD is common and predicted by circulating pro-adrenomedullin. Chest 2014; 146: 328-38.

26. Schuetz P, Marlowe RJ, Mueller B. The prognostic blood biomarker pro-adrenomedullin for outcome prediction in patients with chronic obstructive pulmonary disease (COPD): a qualitative clinical review. Clin Chem Lab Med 2015; 53: 521-39.

27. Huang DT, Angus DC, Kellum JA, et al. Mid-regional pro-adrenomedullin as a prognostic tool in communityacquired pneumonia. Chest 2009; 136: 823-31.

28. Vizza CD, Letizia C, Sciomer S, et al. Increased plasma levels of adrenomedullin, a vasoactive peptide, in patients with end-stage pulmonary disease. Regul Pept 2005; 124: 187-93.

29. Xue Y, Taub P, labal N, Fard A, Clopton P, Maisel A. Midregion pro-adrenomedullin adds predictive value to clinical predictors and Framingham risk score for long-term mortality in stable outpatients with heart failure. Eur J Heart Fail 2013; 15: 1343-9.

30. Potocki M, Ziller R, Mueller C. Mid-regional pro-adrenomedullin in acute heart failure: a better biomarker or just another biomarker? Curr Heart Fail Rep 2012; 9: 24451. 